\title{
Honey reduces the metastatic characteristics of prostate cancer cell lines by promoting a loss of adhesion
}

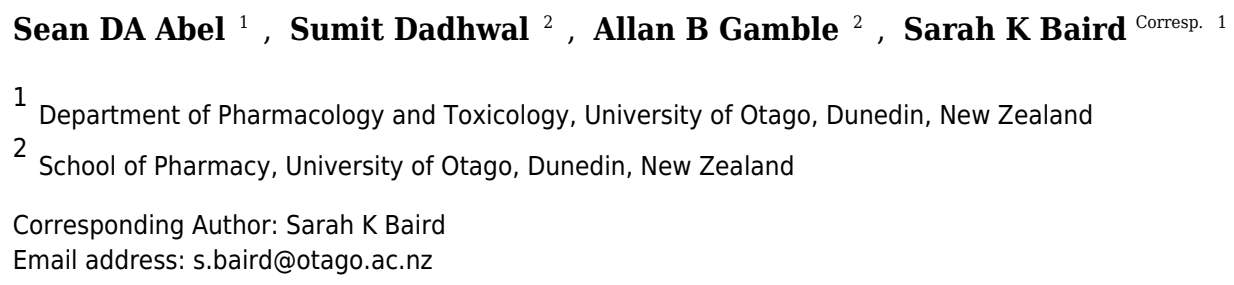

Honey has been shown to have a range of therapeutic effects in humans, with antiinflammatory and anti-bacterial effects among those previously characterised. Here, we examine the possibility of New Zealand thyme, manuka and honeydew honeys, and their major sugar and phenolic components, reducing the development of metastatic cancer. Their activity was examined in vitro, in PC3 and DU145 prostate cancer cell lines, through measuring the compounds' effects on the metastatic characteristics of migration, invasion and adhesion. First, the phenolic compounds gallic acid, caffeic acid, quercetin, kaempferol and chrysin were quantified in the honeys using high performance liquid chromatography, and found in nanomolar concentrations. In a Boyden chamber-based migration assay, nontoxic concentrations of thyme and honeydew honeys reduced cell migration by $20 \%$, and all phenolic compounds except caffeic acid also lowered migration, although a mixture of only the sugars found in honey had no effect. All of the honeys, phenolics and the sugaronly mixture reduced invasive movement of cells through extracellular matrix by up to $75 \%$. Most notably, each of the three honeys and the sugar-only mixture reduced cell adhesion to collagen I by $90 \%$. With the exception of quercetin, phenolic compounds did not reduce adhesion. Therefore, honey and its sugar and phenolic components can lower the metastatic properties of cancer cells, and may do this by preventing effective cell adhesion to the extracellular matrix. The sugars and phenol compounds of honey are much more effective in combination than individually. 
1 Honey reduces the metastatic characteristics of prostate cancer cell lines by promoting a

2 loss of adhesion

3

4 Authors:

5 Sean D.A. Abel (1), Sumit Dadhwal (2), Allan B. Gamble (2), Sarah K. Baird (1*)

6

7 Affiliations:

8 1. Department of Pharmacology and Toxicology, School of Biomedical Sciences, University of

9 Otago, PO Box 56, Dunedin 9054, New Zealand

10 2. School of Pharmacy, University of Otago, PO Box 56, Dunedin 9054, New Zealand

11

12 Corresponding author:

13 Sarah K. Baird

14 s.baird@otago.ac.nz

$15+6434797261$

16

17

18

19

20

21

22 


\section{Abstract}

27 Honey has been shown to have a range of therapeutic effects in humans, with anti-inflammatory 28 and anti-bacterial effects among those previously characterised. Here, we examine the possibility 29 of New Zealand thyme, manuka and honeydew honeys, and their major sugar and phenolic 30 components, reducing the development of metastatic cancer. Their activity was examined in 31 vitro, in PC3 and DU145 prostate cancer cell lines, through measuring the compounds' effects on

32 the metastatic characteristics of migration, invasion and adhesion. First, the phenolic compounds

33 gallic acid, caffeic acid, quercetin, kaempferol and chrysin were quantified in the honeys using

34 high performance liquid chromatography, and found in nanomolar concentrations. In a Boyden 35 chamber-based migration assay, non-toxic concentrations of thyme and honeydew honeys 36 reduced cell migration by $20 \%$, and all phenolic compounds except caffeic acid also lowered 37 migration, although a mixture of only the sugars found in honey had no effect. All of the honeys, 38 phenolics and the sugar-only mixture reduced invasive movement of cells through extracellular 39 matrix by up to $75 \%$. Most notably, each of the three honeys and the sugar-only mixture reduced 40 cell adhesion to collagen I by $90 \%$. With the exception of quercetin, phenolic compounds did not 41 reduce adhesion. Therefore, honey and its sugar and phenolic components can lower the 42 metastatic properties of cancer cells, and may do this by preventing effective cell adhesion to the 43 extracellular matrix. The sugars and phenol compounds of honey are much more effective in 44 combination than individually. 


\section{Introduction}

Honey is made from nectar by honeybees (Apis mellifera), which has been shown to have potential therapeutic benefits in humans. Some of these characteristics, including anti-bacterial, anti-inflammatory, anti-oxidant and anti-hypertensive effects, have been demonstrated in vivo and some only in vitro. These properties are usually attributed to the honey's polyphenol components (Alvarez-Suarez, Giampieri \& Battino, 2013).

The major constituents of honey are sugars, which make up more than $99 \%$ of the dry weight of honey (White \& Doner, 1980). Enzymes, including invertase, diastase and glucose oxidase, in the honey stomach of the bees, convert the nectar-derived polysaccharides into monosaccharides (Winston, 1991). The sugar mixture consists mainly of fructose (40.5\%), glucose $(33.5 \%)$, maltose $(7.5 \%)$ and sucrose $(1.5 \%)$, which is consistent between honeys regardless of the origin of the nectar (Cooper, Molan \& Harding, 2002). However, honey also has many other components, including amino acids, vitamins, minerals, polyphenols and enzymes

64 (White, 1978). The polyphenols, including phenolic acids and flavonoids, make up most of this 65 group. Their composition and proportions vary depending upon the source of honey, with five of 66 the most prevalent and biologically active being quercetin, gallic acid, kaempferol, chrysin and 67 caffeic acid (Alvarez-Suarez, Giampieri \& Battino, 2013; Kassim et al., 2010; Erejuwa, Sulaiman $68 \&$ Wahab, 2014). 

bearing animal models. It has been shown that honey can inhibit cancer cell proliferation and induce apoptosis in a range of cancers including breast, colon, liver and prostate cancers (Fauzi,

72 Norazmi \& Yaacob, 2011; Hassan et al., 2012; Jubri et al., 2012; Tomasin \& Gomes-Marcondes,

73 2011; Tsiapara et al., 2009; Wen et al., 2012).

It is also likely that honeys may have an effect on metastasis, the formation of secondary tumours at other sites in the body, which is responsible for the majority of cancer deaths (Mehlen \& Puisieux, 2006). In metastasis, cancer cells migrate away from the primary tumour site, invade through the local tissue and enter the circulation, infiltrate at a secondary site and finally reestablish tumour growth. The cell processes involved in metastasis are regulated by receptors such as integrins and intracellular signalling proteins that control cell adhesion to the surrounding extracellular matrix, degrade physical barriers such as the basement membrane via

81 proteolysis and increase cell motility (Liotta, Steeg \& Stetler-Stevenson, 1991). The cell moves as a result of cytoskeletal changes mediated by a cycle of actin polymerisation and depolymerisation controlled by the Rho family GTPases, which allows formation of membrane

84 protrusions. The protrusions, and the cell body behind it, attach to and detach from the extracellular matrix in a regulated motion as the cell moves forward (Pollard \& Borisy, 2003). The processes of migration, invasion and adhesion can each be measured separately in vitro to characterise the mechanism of action of effects on metastasis.

Two studies have investigated the effect of honey on metastasis using animal models.

89 Oršolić et al. showed that $2 \mathrm{~g} / \mathrm{kg}$ honey given orally daily before intravenous mammary or

90 fibrosarcoma tumour cell injection into CBA mice reduced tumour formation in the lungs by

91 around 70\%, but had no effect if only given after tumour inoculation (Oršolić et al., 2005). An 
92 earlier study by the same group also examined colon adenocarcinoma in Y59 rats after

93 intraveneous injection. In this study, it was found that honey, given orally for 10 days before

94 tumour inoculation at $1 \mathrm{~g} / \mathrm{kg}$, reduced tumour nodules in the lungs by around 56\% (Oršolić et al., 95 2003).

In vitro, any assessment of honey's potential anti-metastatic activity has been indirect.

97 Moskwa et al. measured the activity of matrix metalloproteinase enzymes (MMPs), important for 98 the invasion process, in U87MG glioblastoma cells, and found that they could be inhibited up to

$9995 \%$ by honeys, although the dose also caused high cytotoxicity (Moskwa et al., 2014).

100 Otherwise, any related investigations have used only single polyphenols that are also found in

101 honey. For example, gallic acid $(3.5 \mu \mathrm{M})$ has been shown to reduce migration in gastric cancer

102 cells AGS by around 75\% after 24 hours in a scratch wound assay and $60 \%$ in a Boyden chamber

103 assay after 48 hours (Ho et al., 2010). Gallic acid also reduced invasion in the U87 glioma cell

104 line by around $50 \%$ at $40 \mu \mathrm{g} / \mathrm{mL}$ (Lu et al., 2010). Caffeic acid ( $4 \mu \mathrm{g} / \mathrm{mL}$ ) has been shown to

105 reduce invasion in PC3 prostate cancer cells by around 50\% (Lansky et al., 2005).

106 The aim of this study was to investigate whether whole honeys, or their main

107 components, sugars or phenolic constituents, might have anti-metastatic properties. We first

108 measured the concentrations of five major phenolic compounds, and then looked at the three

109 main characteristics of metastatic cells, using in vitro assays to measure migration, invasion and

110 adhesion.

112 Materials and Methods

113

114 Materials 
115 Dimethyl sulphoxide (DMSO) was from Scharlau (Barcelona, Spain). RPMI-1640

116 medium, foetal bovine serum (FBS), penicillin streptomycin (PS), PBS and trypsin were from

117 Gibco (Carlsbad, CA). Bovine serum albumin (BSA), 3-(4,5-dimethylthiazol-2-yl)-2,5-diphenyl

118 tetrazolium bromide (MTT), quercetin, caffeic acid, sucrose, maltose, fructose, D-(+)-glucose,

119 formic acid, methanol, sodium bicarbonate, ethyl acetate, sodium hydroxide and hydrochloric

120 acid were from Sigma-Aldrich (St. Louis, MO). Thyme, manuka and honeydew honeys were

121 kindly donated by New Zealand Honey Specialties Limited (Mosgiel, New Zealand).

122 Kaempferol and chrysin were from Sapphire Biosciences (NSW, Australia). Gallic acid was

123 from Abcam (Cambridge, England). Fibronectin, collagen I and Matrigel ${ }^{\circledR}$ were from Corning

124 (New York, USA).

125

126 Preparation of honey and compounds

127 Thyme and manuka honey were from the Central Otago region of New Zealand,

128 produced from the Thyme bush (Thymus vulgaris) or Manuka tree (Leptospermum scoparium).

129 Honeydew honey was collected in the Canterbury region of New Zealand, from the Beech Forest

130 tree (Nothofagus fusca). All honeys were produced by the European honey bee (Apis mellifera).

131 The sugar-only mixture, an artificial honey, was made by combining $40.5 \mathrm{~g}$ fructose, $33.5 \mathrm{~g}$

132 glucose, $7.5 \mathrm{~g}$ maltose and $1.5 \mathrm{~g}$ sucrose in $17 \mathrm{ml}$ double distilled water $\left(\mathrm{ddH}_{2} \mathrm{O}\right)($ Cooper, Molan

$133 \&$ Harding, 2002). Raw honeys were stored at room temperature, with minimal light exposure.

134 Stock honey solutions were prepared by dissolving in warmed serum-free RPMI-1640 medium

135 and sterilized using a $0.22 \mu \mathrm{m}$ filter. Phenolic compounds were dissolved in $100 \%$ DMSO and

136 filtered. Fresh preparations of honeys and compounds were made before each experiment. 
138 Preparation of phenolic extracts

139 The following method was adapted from Wahdan (1998). Thyme, manuka and honeydew

140 honeys were dissolved in warmed MilliQ water to give a final concentration of $20 \%(\mathrm{w} / \mathrm{v})$

141 (10mL or 15.48g honey in $40 \mathrm{~mL}$ MilliQ). After extraction, dried samples were redissolved in $142600 \mu \mathrm{L}$ methanol.

143

144 Free phenol extract preparation

145 Each honey solution $(50 \mathrm{~mL})$ was adjusted to $\mathrm{pH} 3.5$ using concentrated HCl. Sodium

146 bisulfite $(1 \mathrm{~g})$ and ethyl acetate $(50 \mathrm{~mL})$ were mixed with the honey solution in a separating

147 funnel. The mixture was shaken for $1 \mathrm{~min}$ so that phenolic compounds moved into the organic

148 phase. The honey solution was poured off, and the ethyl acetate layer transferred into a separate

149 beaker. A further $50 \mathrm{~mL}$ ethyl acetate was added to the honey solution. These extraction steps

150 were repeated 6 times. The ethyl acetate mixture $(300 \mathrm{~mL}$ total $)$ was concentrated using a rotary

151 evaporator under vacuum $(\sim 240 \mathrm{mbar})$ at $30^{\circ} \mathrm{C}$. Dried compounds were reconstituted

152 (methanol:ethyl acetate, $1: 1$ ), and dried under nitrogen to be stored at $-15^{\circ} \mathrm{C}$.

153

154 Total phenol extract preparation

155 Extra preparation was required in order to hydrolyse phenolic compounds that were

156 bound to sugars via ester bonds. Each honey solution $(25 \mathrm{~mL})$ was combined with $\mathrm{NaOH}(25 \mathrm{~mL}$,

$1573 \mathrm{~N}$ ) and hydrolysed at room temperature for $4 \mathrm{~h}$. Following this, $\mathrm{pH}$ was adjusted to 3.5 using

158 concentrated $\mathrm{HCl}$, and extraction carried out as for the free phenol extraction above.

159

160 Quantification of phenolic compounds by high performance liquid chromatography (HPLC) 
162 Corporation, Japan) on a reversed-phase Gemini $5 \mu \mathrm{m} \mathrm{C18} \mathrm{110 \AA ,} \mathrm{LC} \mathrm{column} \mathrm{(150} \mathrm{x} 4.6 \mathrm{~mm})$

163 (Phenomenex, USA). The method was adapted from Kassim et al. (2010), and consisted of a

164 gradient system to identify and quantify selected phenols in the extracted honey samples. The

165 mobile phase was a binary solvent solution consisting of $\mathrm{A}=0.25 \%$ formic acid and $2 \%$

166 methanol in water, and $\mathrm{B}=100 \%$ methanol. The gradient method was as follows: $0 \mathrm{~min} 10 \% \mathrm{~B}$,

$16720 \min 40 \% \mathrm{~B}, 30 \mathrm{~min} 45 \% \mathrm{~B}, 50 \min 60 \% \mathrm{~B}, 52 \mathrm{~min} 80 \% \mathrm{~B}, 60 \mathrm{~min} 90 \% \mathrm{~B}, 62 \mathrm{~min} 10 \% \mathrm{~B}$ until

$16865 \mathrm{~min}$. Honey phenolic compounds were detected using a diode array where the spectra were

169 monitored at 370nm (kaempferol and quercetin), 325nm (caffeic acid), and 270nm (gallic acid

170 and chrysin).

171 Calibration curves of standards were used to identify and quantify phenolic compounds

172 within honey samples. Identification was completed by comparing standard retention time and

173 absorbance spectrums against samples. Sample spiking was used to increase the confidence of

174 peak identification. To resolve quantification issues due to split and shouldered peaks, the valley-

175 to-valley integration method was employed.

177 Cell Culture

178 Human prostate cancer cell lines PC3 (more metastatic) and DU145 (less metastatic)

179 were a gift from Prof. Rosengren (University of Otago, New Zealand). Cells were maintained in

180 RPMI-1640 medium, supplemented with 5\% FBS, 100U/mL penicillin, $100 \mu \mathrm{g} / \mathrm{mL}$ streptomycin

181 and $2 \mathrm{~g} / \mathrm{L}$ sodium bicarbonate. Cells were incubated in $5 \% \mathrm{CO}_{2} / 95 \% \mathrm{O}_{2}$ humidified air at $37^{\circ} \mathrm{C}$.

182

183 Boyden chamber migration assay 


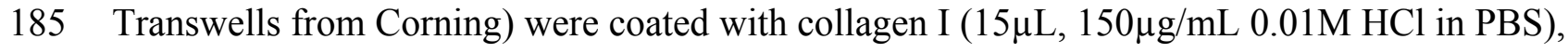

186 left to dry under sterile conditions for $1 \mathrm{~h}$, washed twice with PBS and dried for a further $1 \mathrm{~h}$.

$18730 \times 10^{3}$ PC3 cells in serum free growth medium were seeded into the upper chamber. The bottom

188 chamber contained 5\% serum-containing growth medium. Both upper and lower chambers were

189 treated for $48 \mathrm{~h}$ with compounds at previously established maximal non-cytotoxic concentrations

190 as follows: $1 \%(\mathrm{w} / \mathrm{v})$ honey, $25 \mu \mathrm{M}$ quercetin, $10 \mu \mathrm{M}$ gallic acid, $50 \mu \mathrm{M}$ caffeic acid, $150 \mu \mathrm{M}$

191 kaempferol or $100 \mu \mathrm{M}$ chrysin (Abel \& Baird, 2018). A vehicle control of $0.1 \%$ DMSO, the

192 highest concentration added, was used. Following treatment incubation, MTT solution

$193(0.5 \mathrm{mg} / \mathrm{mL})$ was added to upper and lower chambers, and plates incubated for a further $3 \mathrm{~h}$

194 (Mosmann, 1983). Following this, a cotton tip was used to remove formazan crystals from the

195 upper chamber. The undersides of the inserts were exposed to DMSO to dissolve formazan

196 crystals from migrated cells. Absorbances were measured at 560nm. Data were expressed as a

197 percentage of migrated cells compared to a vehicle control .

198

199 Boyden chamber invasion assay

This assay was used to determine the in vitro invasive ability of PC 3 prostate cancer cells

through Matrigel ${ }^{\circledR}$, a solution containing extracellular matrix and basement membrane proteins

resembling the structural parts of the tumour-surrounding stromal environment (Hughes, Postovit

\& Lajoie, 2010). The invasion of cells from the inside of the insert towards the underside was

measured while the cells were exposed to compounds at previously established non-cytotoxic concentrations for $72 \mathrm{~h}: 0.5 \%(\mathrm{w} / \mathrm{v})$ honey, $5 \mu \mathrm{M}$ quercetin, $10 \mu \mathrm{M}$ gallic acid, $50 \mu \mathrm{M}$ caffeic acid, 
207 the highest concentration added, was used. Matrigel ${ }^{\circledR}$ was added to the upper chamber of inserts,

208 and after $1 \mathrm{~h}$, was washed with serum-free growth medium. The remainder of the method

209 proceeded as for the migration assay, although the treatment duration was $72 \mathrm{~h}$. Data were

210 expressed as a percentage of migrated cells compared to a vehicle control.

212 Cell adhesion assay

213 In order to assess the ability of honey to affect PC3 prostate cancer cell adherence in

214 vitro, an assay to measure attachment was used (Jin et al., 2000). 96-well plates were coated with

215 collagen I ( $20 \mu \mathrm{L}, 5 \mathrm{~g} / \mathrm{mL}, 0.01 \mathrm{M} \mathrm{HCl}$ in PBS) or fibronectin $(20 \mu \mathrm{L}, 5 \mu \mathrm{g} / \mathrm{mL}$ in PBS) and dried

216 for $1 \mathrm{~h}$. Plates were washed twice in PBS. BSA (1\%, in PBS) was added to each well for $1 \mathrm{~h}$.

217 Wells were washed twice with PBS and left to dry for a further $2 \mathrm{~h} .1 \times 10^{4} \mathrm{PC} 3$ or DU145 cells in

218 growth medium were added to each well. Cells were treated with honey or compound at

219 concentrations that were non-toxic over $24 \mathrm{~h}$ as shown previously $\mathrm{y}^{24}$ and were left to incubate for

22030 and $60 \mathrm{~min}(\mathrm{PC} 3)$ or 30,60 and $90 \mathrm{~min}$ (DU145). The concentrations used were $0.5-5 \%$ for

221 honeys, up to $150 \mu \mathrm{M}$ for quercetin and kaempferol, up to $50 \mu \mathrm{M}$ for chrysin and caffeic acid, and

222 up to $10 \mu \mathrm{M}$ for gallic acid. A vehicle control of $0.1 \%$ DMSO, the highest concentration added,

223 was used. Wells were aspirated and washed twice in PBS. RPMI 1640 with 5\% FBS with MTT

$224(0.5 \mathrm{mg} / \mathrm{mL})$ was added to each well and incubated for $3 \mathrm{~h}$. The formazan crystals were

225 solubilised in DMSO and absorbances were measured at $560 \mathrm{~nm}$. Data were expressed as a

226 percentage of vehicle control adhered cells.

227

228 Statistics 
231 (*). For cytotoxicity experiments, a two-way ANOVA followed by a Bonferroni post-hoc test

232 was used to determine the effect of both concentration and time on cell death. Where normality

233 was assumed, outliers were identified using the Online GraphPad Prism Grubbs' Test, and were

234 removed from data sets according to recommendations based on calculated critical $\mathrm{Z}$ values.

235

236

237

238

239

240

241 Results

242

243 Quantification of phenolic compounds in honey by HPLC

Since we were interested in quantifying the effect of whole honeys and their main phenolic constituents on the pro-metastatic properties of prostate cancer cell lines, we first optimised a method to extract and measure both total and free phenols, including gallic acid, 248 caffeic acid, quercetin, kaempferol and chrysin, from the thyme, manuka and honeydew honeys. 249 An HPLC gradient system was developed to ensure sufficient separation of the compounds, 250 which were identified using calibration curves with standards, verified by sample spiking. The 
251 valley-to-valley integration method was used for analysis, due to frequent split and shouldered 252 peaks (Fig. 1).

Table 1 shows the concentrations of free and total phenols found in the thyme, manuka

254

256

257

259

260

261

262

264 265 266

267 268

269

270

271

272

and honeydew honeys, as both $\mu \mathrm{g} / 100 \mathrm{~g}$ of honey and in $\mathrm{nM}$, allowing comparison with the concentrations used in later experiments. The retention times, in minutes $( \pm \mathrm{SEM}, \mathrm{n}=18)$, were $4.3 \pm 0.02$ for gallic acid, $20.3 \pm 0.02$ for caffeic acid, $35.3 \pm 0.12$ for quercetin, $41.1 \pm 0.1$ for kaempferol and $50.0 \pm 0.07$ for chrysin.

The amounts of each phenol varied widely by up to tenfold between the three honey types. Gallic acid recorded the highest concentration among the phenolic compounds throughout all honeys with a total of $1082.88 \pm 16.25 \mu \mathrm{g} / 100 \mathrm{~g}$ free-phenol extracted honeydew honey, which becomes a low $\mu \mathrm{M}$ concentration in the $5 \%(\mathrm{w} / \mathrm{v})$ honey solution used in later assays.

Quercetin recorded the lowest concentration among all phenolic compounds, being only detectable in free phenol-extracted thyme and manuka honey. A higher recovery of gallic acid and caffeic acid were observed in most total phenol extracts, which were in contrast to all other compounds that showed a higher recovery in free phenol extracts.

\section{Effect of honey and its constituents on prostate cancer cell migration and invasion}

(1)
Migration and invasion were tested in Boyden chambers, with the addition of Matrigel for the invasion assay. For these experiments, only the PC3 cell line was used, since the DU145 cell line is not very migratory, and was found not to move through the Boyden chamber. The tests were conducted using the previously reported highest non-toxic concentrations of honey of 
$2731 \%$ for the 48 hour-long migration assay, and $0.5 \%$ for the 72 hour-long invasion assay (Abel \& 274 Baird, 2018).

275 The $1 \%$ thyme or honeydew honey caused a small but significant reduction in PC3 cell 276 migration compared to vehicle-treated control of $20.59 \pm 4.90 \%$ and $18.90 \pm 1.62 \%$

277 respectively (Fig. 2A). The manuka honey and the sugar-only mixture did not cause any

278 reduction in cell migration, suggesting that non-sugar related compounds in honey may be 279 responsible for the effect on migration.

All the non-toxic concentrations of phenolic compounds tested, with the exception of 281 caffeic acid, caused a decrease in PC3 cell migration (Fig. 2B). Gallic acid (10 $\mu \mathrm{M})$ caused the 282 greatest reduction in migration of $49.10 \pm 8.33 \%$ compared to vehicle (DMSO)-treated control. 283 Together, these results demonstrated that phenolic compounds found in honey possess anti284 metastatic activity against PC3 cells, however not all compounds have similar potency.

When invasion was measured, which looks at PC3 cell movement as well as the capacity 286 to move through the Matrigel matrix, $0.5 \%(\mathrm{w} / \mathrm{v})$ thyme, manuka or honeydew honey caused a significant reduction compared to control of $50.53 \pm 4.10 \%, 60.44 \pm 9.71 \%$ and $75.32 \pm 0.19 \%$ respectively (Fig. 2C). The sugar-only mixture caused a $46.77 \pm 17.01 \%$ reduction in cell invasion, however it was not statistically significant. These changes were much greater than the reduction of migration, suggesting that honey particularly reduces the cells' ability to move 291 through Matrigel.

Invasion was also lowered by most of the phenolic compounds, with quercetin $(10 \mu \mathrm{M})$ 293 and caffeic acid $(50 \mu \mathrm{M})$ resulting in reductions of $45.28 \pm 0.64 \%$ and $14.44 \pm 1.17 \%$ 294 respectively (Fig. 2D). Further, chrysin $(100 \mu \mathrm{M})$ and gallic acid $(10 \mu \mathrm{M})$ reduced invasion by $29539.57 \pm 14.57 \%$ and $29.03 \pm 15.86 \%$ respectively, however these were not statistically 
296 significant. Finally, kaempferol only recorded a reduction in invasion of $5.04 \pm 2.11 \%$. Overall,

297 the reductions in invasion caused by the phenolic compounds were comparable to those in

298 migration, with the exception of kaempferol and caffeic acid.

299

300 Effects of honey and honey constituents on prostate cancer cell adhesion

301

302

Thyme, manuka and honeydew honeys caused a much greater, concentration-dependent

303 decrease in cell adhesion, compared to their effects on migration and invasion, in both PC3 and

304 DU145 cells $(P<0.05)$ (Fig. 3). This was assessed after 30 and 60 minutes of exposure to the

305 honeys in PC3 cells, and 60 and 90 minutes in the DU145 cells, which required longer to become

306 adherent. DU145 cells were much more sensitive to the effect of the honeys, with their adhesion

307 to collagen I being nearly completely prevented by $2 \%(w / v)$ honey, down to $8.98 \pm 4.65 \%$ of

308 vehicle-treated control with honeydew honey after 60 minutes, whereas the PC3 cells required 5

$309 \%(w / v)$, reaching $8.93 \pm 3.69 \%$ with honeydew honey at 60 minutes. In PC3 cells, the sugar-

310 only mixture was also effective at reducing adhesion, at $3 \%(\mathrm{w} / \mathrm{v})(33.18 \pm 25.05 \%)$ and $5 \%$

$311(\mathrm{w} / \mathrm{v})(16.51 \pm 4.68 \%)$ at 60 minutes, but in the DU145 cells, lower concentrations of the sugar-

312 only mixture actually increased adhesion (although not significantly) before strongly lowering it

313 at $5 \%(\mathrm{w} / \mathrm{v})$, to $21.88 \pm 13.01 \%$ at 90 minutes.

314 When cells were adhering to fibronectin, the results were very different (Fig. 4). In PC3

315 cells, while the honeys did lower adhesion in a statistically significant way, the effect was no

316 longer large and nor was it concentration-dependent. The sugar-only mixture and the honeys

317 gave similar levels of adhesion reduction, with the maximum reduction being found at 60

318 minutes with $4 \%(\mathrm{w} / \mathrm{v})$ manuka honey, at $67.15 \pm 8.33 \%$. In DU145 cells, the effects were also 
319 much smaller than they had been with collagen I, although the reduction was much greater than

320 with the PC3 cells. Adhesion was lowered to $42.33 \pm 1.05 \%$ at 90 minutes by $3 \%(w / v)$

321 honeydew honey. Again, the effects were not concentration-dependent. With the DU145 cells,

322 however, the changes in adhesion with the sugar-only mixture were very different from what was

323 seen with the PC3 cells. With most concentrations, an increase in adhesion was found, up to

$324190.97 \pm 5.46 \%$ with $4 \%(\mathrm{w} / \mathrm{v})$ at 90 minutes.

325 Adhesion measurements for both cell lines to collagen I and fibronectin were used to 326 determine whether the five honey-derived phenolic compounds were responsible for the loss of

327 cell attachment seen from honey administration (Fig. 5). At 60 min, no compound had any effect

328 on either PC3 or DU145 cell adhesion to fibronectin at any concentration. Only quercetin and

329 kaempferol $(150 \mu \mathrm{M})$ caused any significant change to cell adhesion to collagen I. Quercetin

$330(150 \mu \mathrm{M})$ caused a reduction in PC3 cell adhesion to collagen I of $47.14 \pm 10.27 \%$. Kaempferol

$331(150 \mu \mathrm{M})$ caused an increase of PC3 and DU145 cell adhesion to collagen I of $117.20 \pm 11.10 \%$

332 and $104.10 \pm 10.09 \%$, respectively.

333

334

335

336

337 Discussion

338

We have shown that honey has anti-metastatic activity in two prostate cancer cell lines, in an in vitro situation in which their unmetabolised forms are in contact with the cancer cells. We

341 have also examined some of the constituents of honey, including the major sugars and five of the 
342 main phenolic compounds, and have shown that they can partially inhibit some metastatic

343 properties as well. Whole honeys, as well as sugars, to a lesser extent, could prevent cell

344 adhesion to collagen I, although phenolic compounds were not effective. Honeys and quercetin

345 also strongly reduced invasion, but the effect on migration was much smaller.

346 We began by measuring the concentrations of five phenolic compounds in whole honeys,

347 chosen due to their abundance and reported biological activity. An enhanced HPLC gradient

348 system was developed which improved upon previously reported methodologies used with honey

349 (Yao et al., 2003) and allowed a more sensitive detection and accurate calculation of the

350 phenolic concentrations. For example, quercetin was found in thyme and manuka honeys,

351 whereas using other methods, it has previously been undetectable in thyme honey (El-Hady \&

352 Shaker, 2013).

353 The phenolic compounds were measured as both free and total phenols. Free phenolic

354 extract samples contained the unbound phenolic compounds (aglycones) within the honey, which

355 were readily extracted by ethyl acetate. Total phenolic extract samples contained both phenolic

356 aglycones and bound phenolic glycosides which required the hydrolysis of the glycosidic ester

357 bonds to release phenolic aglycones before they could be extracted into an organic solvent 358 (Wahdan, 1998).

359 A higher recovery of gallic acid and caffeic acid were observed in total phenol than in 360 free phenol extracts, which were in contrast to the flavonoid compounds that showed a higher

361 recovery in free phenol extracts. An explanation for this may be that flavonoids in honey exist

362 mainly as aglycones and were detected in the free phenol samples fully, however, the two

363 phenolic acids caffeic acid and gallic acid exist predominantly as glycosides from pollen, and

364 therefore may require hydrolysis (as used for the 'total' samples) (Ferreres et al., 1991). The only 
365 exception was the gallic acid in manuka honey, of which a greater amount was detected in the

366 free phenol extracts. This could be explained by the fact that manuka honey has been reported to

367 have a high concentration of glucose oxidase which can produce hydrogen peroxide (White \&

368 Doner, 1980), and radicals including hydrogen peroxide are able to hydrolyse the glycosidic

369 bonds between phenolics and sugars (Brudzynski et al., 2011; Hussein et al., 2011). As we found

370 here, gallic acid was previously described as the predominant phenolic acid in both Australian

371 and New Zealand honeys (Yao et al., 2003; Yao et al., 2004).

372 The effect of both whole honey and phenolic compounds on cell migration in Boyden

373 chambers was limited but significant. The effect was found with both thyme and honeydew

374 honeys, but the reductions were not as large as those caused by kaempferol and chrysin, of up to

$37550 \%$. The sugar-only mixture, manuka honey and other phenolics did not affect migration. In

376 contrast, Ho et al. reported that gallic acid $(3.5 \mu \mathrm{M})$ could inhibit the migration of gastric cancer

377 AGS cells by 60\% in Boyden chambers (Ho et al., 2010), but this was measured after only 6

378 hours of migration following 48 hours of exposure to gallic acid in other wells, quite a different

379 set-up from that used here.

380 Interestingly, the effect of honeys on invasion, the movement through Matrigel as well as

381 the Boyden chamber, was much more pronounced, with honeydew honey having the greatest

382 effect in reducing invasion by around $75 \%$, but with all honeys having a large significant effect.

383 Of the phenolic compounds, only quercetin and caffeic acid showed statistically significant

384 reductions, but there was a trend towards reduction for chrysin, gallic acid and the sugar-only

385 mixture as well.

386 This demonstrates that honeys can inhibit the invasion process more strongly than the

387 migration process, and suggests that a major point of inhibition is likely to be a part of a pathway 
388 that is more important for invasion than migration. Although we have not investigated this here,

389 the mechanism of action may be through inhibition of the MMPs, which are among the proteases

390 expressed at the leading edge of metastasising cells, where they facilitate the breakdown of the

391 extracellular matrix (Friedl \& Wolf, 2003). Ho et al. showed that gallic acid could reduce

392 gelatinolytic activity of MMP-2 and MMP-9, possibly via NF-kB (Ho et al., 2010). It has been

393 shown that honey can reduce the expression and nuclear translocation of NF-kB both in vivo and

394 in vitro (Batumalaie et al., 2013; Hussein et al., 2013), although honeys were also shown not to

395 inhibit NF-kB activity in glioblastoma cells U87MG (Moskwa et al., 2014). However, Moskwa

396 et al. did show that honeys could reduce enzymatic activity of MMP-2 and MMP-9 (Moskwa et

397 al., 2014). Fir honey also inhibited migration of human keratinocytes through the reduced

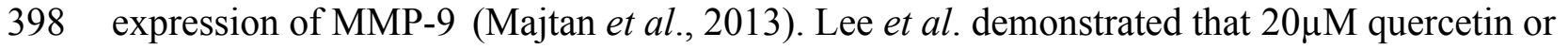

399 luteolin could inhibit the secretion of MMPs in the MIA PaCa-2 cell line (Lee et al., 2004).

400 Quercetin $(50-100 \mu \mathrm{M})$ has also been reported to downregulate the expression of both MMP-2

401 and -9 in PC3 cells (Vijayababu et al., 2006).

402 Phenolic compounds have also been previously shown to affect other parts of the cell

403 migration process, including both Rho family GTPases and integrin expression, although this has

404 not been demonstrated in cancer cells. For example, gallic acid $(25-100 \mu \mathrm{M})$ inhibited RhoA

405 protein expression and activity in scar-derived fibroblasts after TGF $\beta$ stimulation (Hsieh et al.,

406 2016). In $\mathrm{L} 929$ fibroblasts, following treatment with $20 \mu \mathrm{M}$ quercetin for 24 hours, $\alpha_{V}$ integrin

407 was upregulated by $18 \%$, and $\beta 1$ integrin was similarly downregulated (Doersch et al., 2017).

408 Some of these concentrations were much higher than those used in our study, however there may

409 have been a cumulative effect of the combination of lower concentrations of many phenolic

410 compounds. 
Another necessary feature of the migration and invasion processes is adhesion to the

412 extracellular matrix. For the first time, it was shown that over the short 30-90 minute timespan of

413 the adhesion assay using collagen I, honey caused a loss of cell adhesion of more than $90 \%$ in

414 both cell lines, although the DU145 cell line was more sensitive. The sugar constituents in honey

415 do appear to play a role in this loss of adhesion, but do not account for the full effect. When

416 fibronectin was used instead of collagen I, the reduction in adhesion was greatly reduced in the

417 PC3 cells. In the DU145 cells, a decrease in adhesion of up to 50\% was still found, but the sugar-

418 only mixture increased, rather than decreased, adhesion, suggesting that the mechanism of action

419 of the sugars is very much dependent upon the protein substrate. The differences in adhesion

420 changes between the two cell types may relate to their expression of integrins. DU145 cells have

421 been shown to highly express $\alpha_{\mathrm{V}}$ and $\beta 1$ integrins, which preferentially bind to fibronectin, and

422 may reduce migration and result in a less invasive phenotype compared to PC3 cells (Ruoslahti

423 \& Giancotti, 1989; Witkowski et al., 1993). The increased invasiveness of PC3 cells compared to

424 DU145 cells has instead been attributed to the expression of $\alpha 6$ and $\beta 1$ integrins, which bind

425 better to collagen and laminin (Witkowski et al., 1993; Suyin, Holloway \& Dickinson, 2013).

426 Collagens, including collagen I, are deposited at a higher rate in tumours, often in a linearised

427 manner, which increases stromal stiffness and contributes to cancer cell migration (Zhu et al.,

428 1995; Egeblad, Rasch \& Weaver, 2010). Thus, the possibility of reducing the adhesion of

429 prostate cells to collagen would, if translatable in vivo, be of potential therapeutic benefit.

430 By contrast, phenolic compounds do not appear to play a role in reducing prostate cancer

431 cell adhesion. The highest concentration of quercetin $(150 \mu \mathrm{M})$ only lowered adhesion of the PC3

432 cells attaching to collagen I, and $150 \mu \mathrm{M}$ kaempferol increased adhesion for both cell lines on

433 collagen I. Quercetin may affect adhesion through the Epidermal Growth Factor Receptor, which 
434 mediates DU145 cell adhesion to collagen I (Lamb, Zarif \& Miranti, 2011) and can be

435 downregulated by quercetin (Kumar et al., 2008; Bhat et al., 2014). We note that to observe

436 biological activity in our assays with these compounds, much higher $(\mu \mathrm{M})$ concentrations of the

437 phenolic compounds were required than are found within the honey and therefore any effects are 438 very unlikely to be due to a single phenolic compound.

439 The lack of effect of phenolic compounds on adhesion of prostate cancer cells was

440 unexpected, given the role of these compounds in the adhesion process in other cell types. There

441 may be some cell-type or integrin-subtype specificity. For example, chrysin $(3 \mu \mathrm{M}$ and $10 \mu \mathrm{M})$

442 was shown to inhibit collagen-induced platelet aggregation, by reducing P-selectin and integrin

$443 \alpha \mathrm{IIb} \beta 3$ signaling (Liu et al., 2016), and caffeic acid at up to $100 \mu \mathrm{M}$ could also lower platelet

444 aggregation, through the same two mechanisms ( $\mathrm{Lu}$ et al., 2015). Caffeic acid at 1-20 $\mathrm{MM}$ also

445 lowered adherence of monocytes to human umbilical vein endothelial cells, through suppression

446 of six different adhesion molecules and integrins (Lee et al., 2012).

It is often assumed that phenolic compounds are responsible for the biological activity of 448 many natural products, including honeys. As honey contains multiple polyphenols, the effect of combination treatment in vivo and in vitro is of interest. We found that phenolic compounds were

450 present in honey in the $\mathrm{nM}$ range (Table 1), however when individually used in vitro at $\mu \mathrm{M}$ 451 ranges, they demonstrated minimal anti-metastatic properties. This suggests that the benefit of 452 honey

Inhibition of cancer cell adhesion by whole honey has not previously been reported.

454 Maddocks et al. reported that manuka honey $(16-50 \% \mathrm{w} / \mathrm{v})$ could inhibit the adhesion of 8

455 bacteria strains to fibronectin, fibrinogen and collagen (Maddocks et al., 2013). This was thought 
456 to be due to a reduction in fibronectin binding proteins, as well as the inhibition of biofilm

457 production (Maddocks et al., 2013; Maddocks et al., 2012). In metastasis, the cell must be able

458 to regulate its attachment to the surroundings in order to move forward. The level of disruption

459 that treatment with honey causes to this process would leave metastasis unable to proceed

460 (Bendas \& Borsig, 2012).

461 We have also made the novel finding that the sugar components of honeys, as well as the 462 phenolics, play a role in its in vitro inhibition of cancer adhesion, migration and invasion. Sugars 463 may act as antioxidants in the body, in a similar way to that reported for polyphenols. A single 464 oral administration of honey $(1.5 \mathrm{~g} / \mathrm{kg})$ in humans was shown to increase the total phenolic, 465 antioxidant and reducing capacity of the plasma. The sugar-only control, corn syrup, did not 466 increase the total plasma phenolic levels, however, it did significantly increase plasma 467 antioxidant capacity (Schramm et al., 2003), most likely through the formation of Maillard 468 products or by acting as reducing sugars (White \& Doner, 1980; Maillard, 1912). This suggests 469 that the activity of honey is due to presence of both phenolics and sugars, and may enhance its 470 overall biological activity compared to other natural phenol sources lacking in sugar.

471

\section{Conclusions}

473

474 We have shown that honeys and some of their constituents are able to inhibit pro475 metastatic properties including migration and invasion in prostate cancer cell lines. This is likely 476 to be related to a blocking of the adhesion process, which has been shown for the first time to be 477 particularly strongly downregulated by honeys, and is a process that contributes to both 
478 migration and invasion. Further investigation of the mechanisms of action of honey compound

479 combination effects in metastasis are warranted.

480

481

482

483

484

485

486

487

488

489

490

491

492

493

494

495

496

497

498

499

500 


\section{References}

503 S.D.A. Abel and S.K. Baird, Honey is cytotoxic towards prostate cancer cells but interacts with

504 the MTT reagent: considerations for the choice of cell viability assay. Food Chem. 2018, 241, $505 \quad 70-78$.

506

507 J. Alvarez-Suarez, F. Giampieri and M. Battino, Honey as a source of dietary antioxidants:

508 structures, bioavailability and evidence of protective effects against human chronic diseases,

509 Curr. Med. Chem. 2013, 20, 621-638.

510

511 K. Batumalaie, S.S. Zaman, Y. K. Mohd, I. I. Shah, S.S. Devi and R. Qvist, Effect of gelam

512 honey on the oxidative stress-induced signaling pathways in pancreatic hamster cells. Int. J.

513 Endocrinol. 2013, 367312.

514

515 G. Bendas and L. Borsig, Cancer Cell Adhesion and Metastasis: Selectins, Integrins, and the

516 Inhibitory Potential of Heparins, Int. J. Cell Biol. 2012, 676731.

517

518 F.A. Bhat, G. Sharmila, S. Balakrishnan, P.R. Singh, N. Srinivasan and J. Arunakaran, 519 Epidermal growth factor-induced prostate cancer (PC3) cell survival and proliferation is 520 inhibited by quercetin, a plant flavonoid through apoptotic machinery. Biomed. Prev. Nutr. 2014, $521 \quad 4,459-468$. 
523 K. Brudzynski, K. Abubaker, L. St-Martin and A. Castle, Re-examining the role of hydrogen

524 peroxide in bacteriostatic and bactericidal activities of honey. Front. Microbiol. 2011, 2, 213.

525

526 R.A. Cooper, P.C. Molan and K.G. Harding, The sensitivity to honey of Gram-positive cocci of 527 clinical significance isolated from wounds. J. Appl. Microbiol. 2002, 93, 857-863.

529 K.M. Doersch, M.K. Newell-Rogers, The impact of quercetin on wound healing relates to 530 changes in aV and b1 integrin expression. Exp. Biol. Med., 2017, 242, 1424-1431.

531

532

533

534

535

536

537

538

539

540

541

542

543

544

M. Egeblad, M.G. Rasch and V.M. Weaver, Dynamic interplay between the collagen scaffold and tumor evolution. Curr. Opin. Cell Biol. 2010, 22, 697-706.

F.K.A. El-Hady and K.H. Shaker, Honey Protects Human Low Density Lipoprotein (LDL) from Peroxidation (In vitro study). Int. J. Pharm. Sci. Rev. Res. 2013, 23, 191-197.

O.O. Erejuwa, S.A. Sulaiman and M.S.Wahab, Effects of honey and its mechanisms of action on the development and progression of cancer. Molecules, 2014, 19, 2497-2522.

A.N. Fauzi, M.N. Norazmi and N.S. Yaacob, Tualang honey induces apoptosis and disrupts the mitochondrial membrane potential of human breast and cervical cancer cell lines. Food Chem. Toxicol. 2011, 49, 871-878. 
545 F. Ferreres, F.A. Tomáas-Barberáan, M.I. Gil and F. Tomáas-Lorente, An HPLC technique for

546 flavonoid analysis in honey. J. Sci. Food Agric. 1991, 56, 49-56.

547

548 P. Friedl and K. Wolf, Tumour-cell invasion and migration: diversity and escape mechanisms.

549 Nat. Rev. Cancer, 2003, 3, 362-374.

550

551 M.I. Hassan, G.M. Mabrouk, H. H. Shehata and M.M Aboelhussein, Antineoplastic effects of

552 bee honey and Nigella sativa on hepatocellular carcinoma cells. Integr. Cancer Ther. 2012, 11, $553 \quad 354-363$.

555 H.H. Ho, C.S. Chang, W.C. Ho, S.Y. Liao, C.H. Wu and C.J. Wang, Anti-metastasis effects of 556 gallic acid on gastric cancer cells involves inhibition of NF- $\mathrm{B}$ activity and downregulation of 557 PI3K/AKT/small GTPase signals. Food Chem. Toxicol. 2010, 48, 2508-2516.

558

559 S.C. Hsieh, C.C. Wu, S.L. Hsu, C.H. Feng, J.H. Yen, Gallic acid attenuates TGF- $\beta 1$-stimulated 560 collagen gel contraction via suppression of RhoA/Rho-kinase pathway in hypertrophicscar 561 fibroblasts. Life Sciences, 2016, 161, 19-26.

562

563 C.S. Hughes, L.M. Postovit and G.A. Lajoie, Matrigel: a complex protein mixture required for 564 optimal growth of cell culture. Proteomics, 2010, 10, 1886-1890. 
566 S.Z. Hussein, K.M. Yusoff, S. Makpol and Y.A.M. Yusof, Antioxidant capacities and total

567 phenolic contents increase with gamma irradiation in two types of Malaysian honey. Molecules,

$5682011,16,6378-6395$.

569

570 S.Z. Hussein, Y.K. Mohd, S. Makpol, and Y.A.Y. Mohd, Gelam honey attenuates carrageenan-

571 induced rat paw inflammation via NF-kappaB pathway. PLoS One, 2013, 8, e72365.

572

573 M. Jin, S. He, V. Worpel, S.J. Ryan and D.R. Hinton, Promotion of adhesion and migration of

574 RPE cells to provisional extracellular matrices by TNF-alpha. Invest. Ophthalmol. Vis. Sci. 2000,

575 41, 4324-4332.

576

577 Z. Jubri, Z., N.N.N. Narayanan, N.A. Karim and W.Z.W. Ngah, Antiproliferative activity and 578 apoptosis induction by gelam honey on liver cancer cell line. Int. J. Appl. Sci.Technol. 2012, 2, $579 \quad 35-41$.

580

581 M. Kassim, M. Achoui, M.R. Mustafa, M.A. Mohd and K.M. Yusoff, Ellagic acid, phenolic 582 acids, and flavonoids in Malaysian honey extracts demonstrate in vitro anti-inflammatory 583 activity. Nutr. Res. 2010, 30, 650-659.

584

585

B. Kumar, S. Koul, L. Khandrika, R.B. Meacham and H.K. Koul, Oxidative stress is inherent in 586 prostate cancer cells and is required for aggressive phenotype. Cancer Res. 2008, 68, 1777-1785. 
588 L.E. Lamb, J.C. Zarif and C.K. Miranti, The androgen receptor induces integrin $\alpha 6 \beta 1$ to promote 589 prostate tumor cell survival via NF-אB and Bcl-xL independently of PI3K signaling. Cancer Res. $590 \quad 2011,71,2739-2749$.

591

592 E.P. Lansky, G. Harrison, P. Froom and W.G. Jiang, Pomegranate (Punica granatum) pure 593 chemicals show possible synergistic inhibition of human PC-3 prostate cancer cell invasion 594 across Matrigel. Invest. New Drugs, 2005, 23, 121-122.

L.T. Lee, Y.T. Huang, J.J. Hwang, A.Y.L. Lee, F.C. Ke, C.J. Huang, C. Kandaswami, P.P. Lee 597 and M.T. Lee, Transinactivation of the epidermal growth factor receptor tyrosine kinase and 598 focal adhesion kinase phosphorylation by dietary flavonoids: effect on invasive potential of 599 human carcinoma cells. Biochem. Pharmacol. 2004, 67(11), 2103-2114.

600

601 E.S. Lee, S.H. Park, M.S. Kim, S.Y. Han, H.S. Kim, Y.H. Kang, Caffeic Acid Disturbs

602 Monocyte Adhesion onto Cultured Endothelial Cells Stimulated by Adipokine Resistin. J. Ag. 603 Food Chem. 2012, 60, 2730-2739.

604

605

L.A. Liotta, P.S. Steeg and W.G. Stetler-Stevenson, Cancer metastasis and angiogenesis: an 606 imbalance of positive and negative regulation. Cell, 1991, 64, 327-336.

607

608 G. Liu, W. Xie, A.D. He, X.W. Da, M.L. Liang, G.Q. Yao, J.Z. Xiang, C.J. Gao, Z.Y. Ming, 609 Antiplatelet activity of chrysin via inhibiting platelet $\alpha \operatorname{IIb} \beta 3$-mediated signaling pathway, Mol. 610 Nutr. Food Res. 2016, 60, 1984-1993. 
611

612 Y. Lu, F. Jiang, H. Jiang, K. Wu, X. Zheng, Y. Cai, M. Katakowski, M. Chopp and S.S.T. To,

613 Gallic acid suppresses cell viability, proliferation, invasion and angiogenesis in human glioma 614 cells. Eur. J. Pharmacol. 2010, 641(2-3), 102-107.

615

616 Y. Lu, Q. Li, Y.Y. Liu, K. Sun, J.Y. Fan, C.S. Wang, J.Y. Han, Inhibitory effect of caffeic acid 617 on ADP-induced thrombus formation and platelet activation involves mitogen-activated protein 618 kinases. Sci. Reports, 2015, 5, 13824.

620 S.E. Maddocks, M.S. Lopez, R.S. Rowlands and R.A. Cooper, Manuka honey inhibits the 621 development of Streptococcus pyogenes biofilms and causes reduced expression of two 622 fibronectin binding proteins. Microbiol. 2012, 158, 781-790.

623

624 S.E. Maddocks, R.E. Jenkins, R.S. Rowlands, K.J. Purdy and R.A. Cooper, Manuka honey 625 inhibits adhesion and invasion of medically important wound bacteria in vitro. Future Microbiol. $6268,2013,523-1536$.

627

628 L.C. Maillard, Action of amino acids on sugars. Formation of melanoidins in a methodical way. 629 Compt. Rend. 1912, 154, 66-68.

630

631 J. Majtan, J. Bohova, R. Garcia-Villalba, F.A. Tomas-Barberan, Z. Madakova, T. Majtan, V. 632 Majtan and J. Klaudiny, Fir honeydew honey flavonoids inhibit TNF- $\alpha$-induced MMP-9 
633 expression in human keratinocytes: a new action of honey in wound healing. Arch. Dermatol.

634 Res. 2013, 305(7), 619-627.

635

636 P. Mehlen and A. Puisieux, Metastasis: a question of life or death, Nat. Rev. Cancer, 2006, 6, $637 \quad 449-459$.

638 J. Moskwa, M.H. Borawska, R. Markiewicz-Zukowska, A. Puscion-Jakubik, S.K. Naliwajko, K.

639 Socha and J. Soroczynska, Polish Natural Bee Honeys Are Anti-Proliferative and Anti-

640 Metastatic Agents in Human Glioblastoma multiforme U87MG Cell Line. PLoS One, 2014, 9, $641 \quad$ e90533.

642

643 T. Mosmann, Rapid colorimetric assay for cellular growth and survival: application to 644 proliferation and cytotoxicity assays. J. Immunol. Methods, 1983, 65, 55-63.

645

646 N. Oršolić, S. Terzić, L. Šver and I. Bašić, Honey-bee products in prevention and/or therapy of 647 murine transplantable tumours. J. Sci. Food Agric. 2005, 85, 363-370.

648 N. Oršolić, A. Knezević, L. Sver, S. Terzić and B. Hackenberger, I. Basić I Influence of honey 649 bee products on transplantable murine tumours. Vet. Comp. Oncol. 2003, 1, 216-226.

650

651 T.D. Pollard and G.G. Borisy, Cellular motility driven by assembly and disassembly of actin 652 filaments. Cell, 2003, 112, 453-465.

653

654 E. Ruoslahti and F. Giancotti, Integrins and tumor cell dissemination. Cancer Cells (Cold Spring 655 Harbor, NY: 1989), 1989, 1(4), 119-126. 
657 D.D. Schramm, M. Karim, H.R. Schrader, R.R. Holt, M. Cardetti and C.L. Keen, Honey with 658 high levels of antioxidants can provide protection to healthy human subjects. J. Agric. Food 659 Chem. 2003, 51, 1732-1735.

660

661 P.C. Suyin, A.F. Holloway and J.L. Dickinson, Integrins in Prostate Cancer Invasion and

662 Metastasis in Advances in Prostate Cancer ed. G. Hamilton, InTechOpen, London, UK, 2013, 663 chapter 25.

664

665 R. Tomasin and M.C. Gomes-Marcondes, Oral administration of aloe vera and honey reduces 666 Walker tumour growth by decreasing cell proliferation and increasing apoptosis in tumour tissue. 667 Phytother. Res. 2011, 25, 619-623.

668

669 A.V. Tsiapara, M. Jaakkola, I. Chinou, K. Graikou, T. Tolonen, V. Virtanen and P. Moutsatsou, 670 Bioactivity of Greek honey extracts on breast cancer (MCF-7), prostate cancer (PC-3) and 671 endometrial cancer (Ishikawa) cells: Profile analysis of extracts. Food Chem. 2009, 116, 702672708.

673

674 M.R. Vijayababu, A. Arunkumar, P. Kanagaraj, P. Venkataraman, G. Krishnamoorthy and J. 675 Arunakaran, Quercetin downregulates matrix metalloproteinases 2 and 9 proteins expression in 676 prostate cancer cells (PC-3). Mol. Cell Biochem. 2006, 287, 109-116.

677

678 H.A. Wahdan, Causes of the antimicrobial activity of honey. Infection, 1998, 26, 26-31. 679 
680 C.T. Wen, S.Z. Hussein, S. Abdullah, N.A. Karim, S. Makpol and Y.A. Mohd Yusof, Gelam and 681 Nenas honeys inhibit proliferation of HT 29 colon cancer cells by inducing DNA damage and 682 apoptosis while suppressing inflammation. Asian Pac. J. Cancer Prev. 2012, 13, 1605-1610.

683

684 J.W. White, Honey. Adv. Food Res. 1978, 24, 287-374.

685 J. White and L.W. Doner, in Beekeeping in the United States, Agriculture Handbook, US 686 Department of Agriculture, 1980, Honey composition and properties, 82-91.

687

688 M.L. Winston, The biology of the honey bee, Harvard University Press, MA, USA, 1991.

689

690 C.M. Witkowski, I. Rabinovitz, R.B. Nagle, K.S. Affinito and A.E. Cress, Characterization of 691 integrin subunits, cellular adhesion and tumorgenicity of four human prostate cell lines. $J$. 692 Cancer Res. Clin. Oncol. 1993, 119, 637-644.

693

694 L. Yao, N. Datta, F.A. Tomás-Barberán, F. Ferreres, I. Martos and R. Singanusong, Flavonoids, 695 phenolic acids and abscisic acid in Australian and New Zealand Leptospermum honeys. Food 696 Chem. 2003, 81, 59-168.

697

698 L. Yao, Y. Jiang, R. Singanusong, B. D’Arcy, N. Datta, N. Caffin and K. Raymont, Flavonoids 699 in Australian Melaleuca, Guioa, Lophostemon, Banksia and Helianthus honeys and their 700 potential for floral authentication. Food Res. Int. 2004, 37(2), 166-174. 
702 G.G. Zhu, L. Risteli, M. Mäkinen, J. Risteli, A. Kauppila A and F. Stenbäck,

703 Immunohistochemical study of type I collagen and type I pN-collagen in benign and malignant

704 ovarian neoplasms. Cancer, 1995, 75, 1010-1017.

705

706

707

708

709

710

711

712

713

714

715

716

717

718

719

720

721

722 Figure Legends

723

Fig. 1 Absorption chromatogram of phenolic compounds in thyme honey using HPLC.

724 Representative chromatogram of free (a) or total (b) phenols extracted from thyme honey using

725 ethyl acetate and eluted through a $\mathrm{C}_{18}$ column using HPLC. Detectors were set to $370 \mathrm{~nm}$ for

726 quercetin and kaempferol, $325 \mathrm{~nm}$ for caffeic acid and $270 \mathrm{~nm}$ for gallic acid and chrysin. Peak

727 retention times were compared to standards to identify compounds. 
728 Fig. 2 Effect of honey and honey-derived phenolic compounds on PC3 cell migration and

729 invasion. PC3 cells were placed in Boyden chambers and treated with $1 \%(\mathrm{w} / \mathrm{v})$ thyme, manuka,

730 honeydew or sugar-only mixture (a) or the phenolics quercetin (10 $\mu \mathrm{M})$, gallic acid $(10 \mu \mathrm{M})$,

731 kaempferol $(150 \mu \mathrm{M})$, chrysin $(100 \mu \mathrm{M})$ or caffeic acid $(50 \mu \mathrm{M})(\mathbf{b})$ for $48 \mathrm{~h}$ to measure

732 migration or in Boyden chambers containing Matrigel for $72 \mathrm{~h}$ with $0.5 \%(\mathrm{w} / \mathrm{v})$ thyme, manuka,

733 honeydew or sugar-only mixture (c) or the phenolics quercetin $(10 \mu \mathrm{M})$, gallic acid $(10 \mu \mathrm{M})$,

734 kaempferol $(150 \mu \mathrm{M})$, chrysin $(100 \mu \mathrm{M})$ or caffeic acid $(50 \mu \mathrm{M})(\mathbf{d})$ for $72 \mathrm{~h}$ to measure

735 invasion. Experiments were completed in triplicate, and values were expressed as mean cell

736 migration \pm S.E.M ( $\mathrm{n}=2$ or 3$)$. Data were analysed using a two-tailed Student's t-test. *

$737(p<0.05)$ represents a significant difference between individual treatment and the vehicle-treated

738 cell control of $0.1 \%$ DMSO for phenolics and RPMI-only for honeys.

739 Fig. 3 Effect of honey on PC3 and DU145 cell adhesion to collagen I. (a,b) PC3 and (c,d)

740 DU145 cells were left to adhere to plates coated with collagen I for (a) 30, (b,c) 60 or (d) 90

741 min. Experiments were completed in triplicate, with results expressed as mean percentage of

742 control \pm S.E.M ( $\mathrm{n}=$ minimum of 3$)$. Individual data were analysed using a two-way ANOVA

743 followed by a Bonferroni post-hoc test, where $\mathrm{p}<0.05$ was required for a statistically significant

744 difference. * represents a significant difference between the vehicle-treated control (RPMI only)

745 and individual treatment.

746 Fig. 4 Effect of honey on PC3 and DU145 cell adhesion to fibronectin. (a,b) PC3 and (c,d)

747 DU145 cells were left to adhere to plates coated with collagen I for (a) 30, (b,c) 60 or (d) 90

$748 \mathrm{~min}$. Experiments were completed in triplicate, with results expressed as mean percentage of

749 control \pm S.E.M $(n=3)$. Individual data were analysed using a two-way ANOVA followed by a

750 Bonferroni post-hoc test, where $\mathrm{p}<0.05$ was required for a statistically significant difference. * 
751 represents a significant difference between vehicle-treated control (RPMI only) and individual

752 treatment.

753 Fig. 5 Effect of honey-derived phenolic compounds on PC3 and DU145 cell adhesion. PC3

754 and DU145 cells were treated with (a) quercetin $(0-150 \mu \mathrm{M})$, (b) gallic acid $(0-10 \mu \mathrm{M})$, (c)

755 kaempferol $(0-150 \mu \mathrm{M}),(\mathbf{d})$ chrysin $(0-50 \mu \mathrm{M})$ or $(\mathbf{e})$ caffeic acid $(0-50 \mu \mathrm{M})$ for $60 \mathrm{~min}$.

756 Experiments were completed in triplicate, and values were expressed as mean percentage cell

757 viability \pm S.E.M ( $\mathrm{n}=2$ or 3$)$. Data were analysed using a two-way ANOVA followed by a

758 Bonferroni post-hoc test, where $\mathrm{p}<0.05$ was required for a statistically significant difference. *

759 represents a significant difference between vehicle-treated control (0.1\% DMSO) and individual

760 treatment.

761

762

763

764

765

766

767

768

769

770 


\section{Table $\mathbf{1}$ (on next page)}

HPLC analysis of ethyl acetate extracted phenolic compounds from honey. 
1 Table 1. HPLC analysis of ethyl acetate extracted phenolic compounds from honey.

\begin{tabular}{|c|c|c|c|c|c|}
\hline \multirow[b]{2}{*}{ Compound } & \multirow[b]{2}{*}{ Honey } & \multicolumn{2}{|c|}{$[\mu \mathrm{g} / 100 \mathrm{~g}$ honey] } & \multicolumn{2}{|c|}{$[5 \% \mathrm{w} / \mathrm{v}$ solution $](\mathrm{nM})$} \\
\hline & & Free & Total & Free & Total \\
\hline \multirow[t]{3}{*}{ Gallic Acid } & Thyme & $94.2 \pm 2.5$ & $686.0 \pm 15.2$ & $276.8 \pm 7.5$ & $2016.0 \pm 44.6$ \\
\hline & Manuka & $741.5 \pm 27.4$ & $584.5 \pm 25.9$ & $2179.0 \pm 80.4$ & $1718.0 \pm 76.0$ \\
\hline & Honeydew & $48.1 \pm 6.2$ & $1082.9 \pm 16.3$ & $141.5 \pm 18.2$ & $3183.0 \pm 47.8$ \\
\hline \multirow[t]{3}{*}{ Caffeic Acid } & Thyme & $90.2 \pm 2.7$ & $83.7 \pm 2.7$ & $250.4 \pm 7.6$ & $232.2 \pm 7.5$ \\
\hline & Manuka & $44.8 \pm 3.5$ & $131.3 \pm 17.1$ & $124.3 \pm 9.8$ & $364.4 \pm 47.3$ \\
\hline & Honeydew & $28.9 \pm 2.5$ & $96.6 \pm 9.0$ & $80.2 \pm 7.0$ & $268.0 \pm 25.1$ \\
\hline \multirow[t]{3}{*}{ Quercetin } & Thyme & $38.2 \pm 3.2$ & - & $63.2 \pm 5.3$ & - \\
\hline & Manuka & $10.6 \pm 7.4$ & - & $17.5 \pm 12.2$ & - \\
\hline & Honeydew & - & - & - & - \\
\hline \multirow[t]{3}{*}{ Kaempferol } & Thyme & $45.3 \pm 13.8$ & $33.1 \pm 12.2$ & $79.2 \pm 24.1$ & $57.9 \pm 0.6$ \\
\hline & Manuka & $9.3 \pm 2.6$ & $12.2 \pm 2.0$ & $16.2 \pm 4.6$ & $21.3 \pm 3.5$ \\
\hline & Honeydew & $11.2 \pm 1.8$ & $8.6 \pm 0.2$ & $19.6 \pm 3.1$ & $15.0 \pm 0.3$ \\
\hline \multirow[t]{3}{*}{ Chrysin } & Thyme & $53.0 \pm 0.3$ & $38.1 \pm 0.4$ & $104.3 \pm 0.5$ & $75.0 \pm 0.7$ \\
\hline & Manuka & $77.6 \pm 0.8$ & $72.1 \pm 1.3$ & $152.6 \pm 1.7$ & $141.9 \pm 2.5$ \\
\hline & Honeydew & $46.4 \pm 0.5$ & $26.8 \pm 0.6$ & $91.2 \pm 0.9$ & $52.8 \pm 1.1$ \\
\hline
\end{tabular}

Compound concentrations ( $\mu \mathrm{g} / 100 \mathrm{~g}$ honey) were calculated by comparing the area under the peak to standard calibration curves and were expressed as mean \pm S.E.M $(n=6)$. Concentrations of each compound were also calculated from within a $5 \%(w / v)$ solution of honey used throughout the study (nM). 


\section{Figure 1}

Absorption chromatogram of phenolic compounds in thyme honey using HPLC.

Representative chromatogram of free (a) or total (b) phenols extracted from thyme honey using ethyl acetate and eluted through a $\mathrm{C}_{18}$ column using HPLC. Detectors were set to 370 $\mathrm{nm}$ for quercetin and kaempferol, $325 \mathrm{~nm}$ for caffeic acid and $270 \mathrm{~nm}$ for gallic acid and chrysin. Peak retention times were compared to standards to identify compounds. 
A.

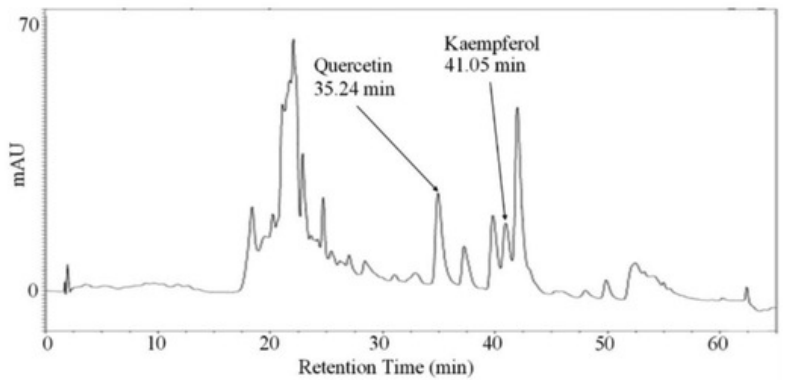

B.

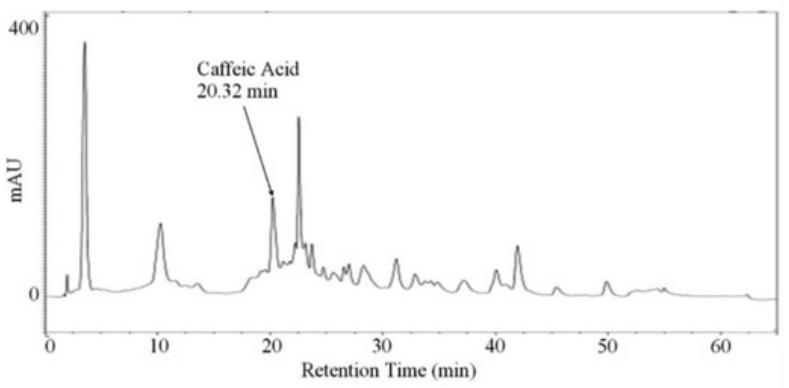

C.

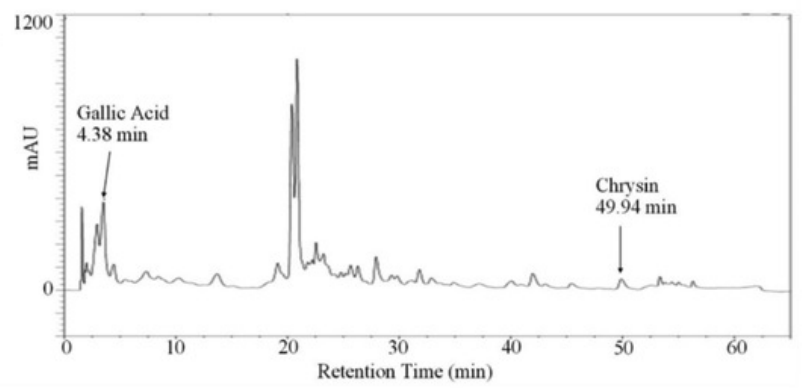

D.
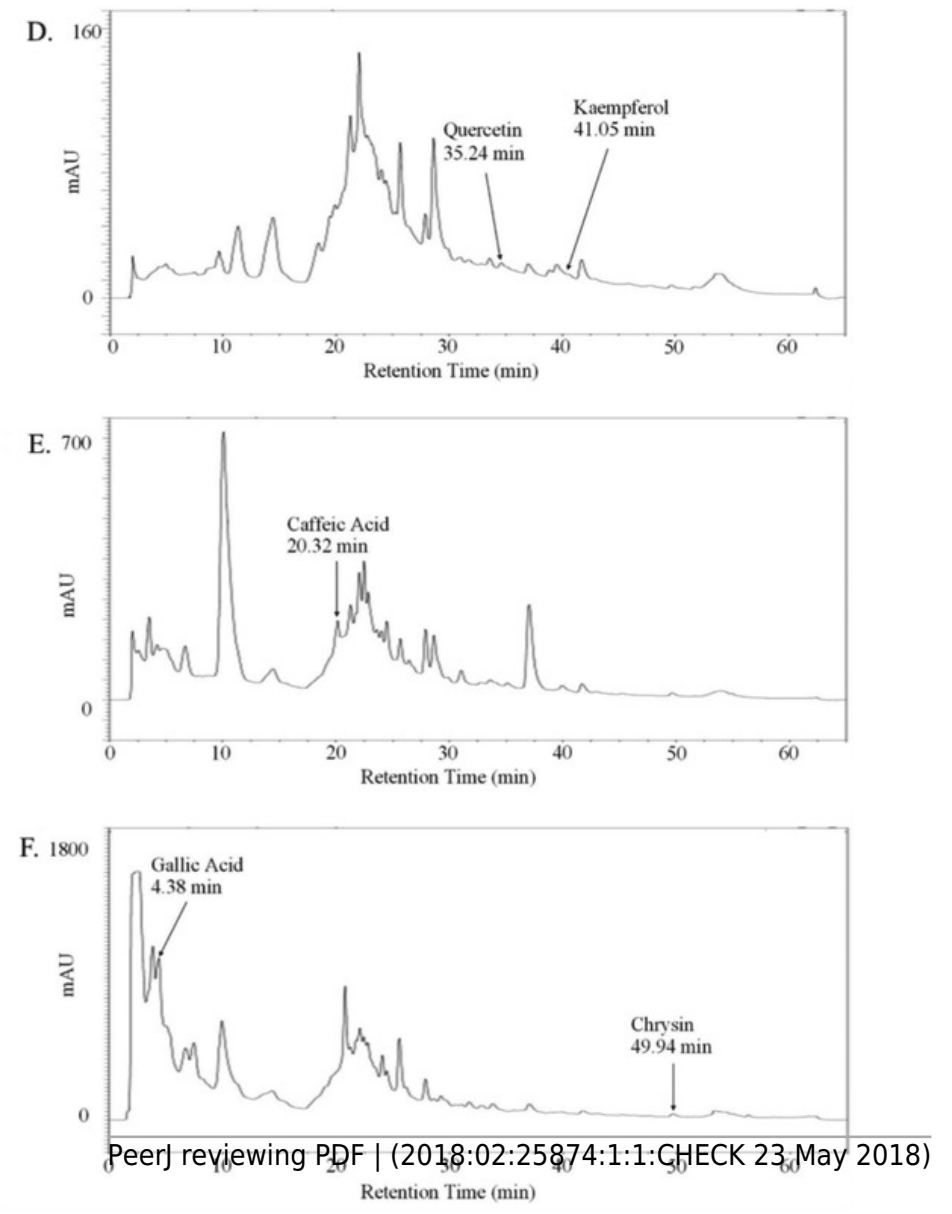


\section{Figure 2 (on next page)}

Effect of honey and honey-derived phenolic compounds on PC3 cell migration and invasion.

PC3 cells were placed in Boyden chambers and treated with 1\% (w/v) thyme, manuka, honeydew or sugar-only mixture (a) or the phenolics quercetin $(10 \mu \mathrm{M})$, gallic acid $(10 \mu \mathrm{M})$, kaempferol $(150 \mu \mathrm{M})$, chrysin $(100 \mu \mathrm{M})$ or caffeic acid $(50 \mu \mathrm{M})(\mathbf{b})$ for $48 \mathrm{~h}$ to measure migration or in Boyden chambers containing Matrigel for $72 \mathrm{~h}$ with $0.5 \%(\mathrm{w} / \mathrm{v})$ thyme, manuka, honeydew or sugar-only mixture (c) or the phenolics quercetin $(10 \mu \mathrm{M})$, gallic acid $(10 \mu \mathrm{M})$, kaempferol $(150 \mu \mathrm{M})$, chrysin $(100 \mu \mathrm{M})$ or caffeic acid $(50 \mu \mathrm{M})(\mathbf{d})$ for $72 \mathrm{~h}$ to measure invasion. Experiments were completed in triplicate, and values were expressed as mean cell migration \pm S.E.M ( $n=2$ or 3). Data were analysed using a two-tailed Student's ttest. $*(p<0.05)$ represents a significant difference between individual treatment and the vehicle- un treated cell control of $0.1 \%$ DMSO for phenolics and RPMI-only for honeys . 
PeerJ

A.

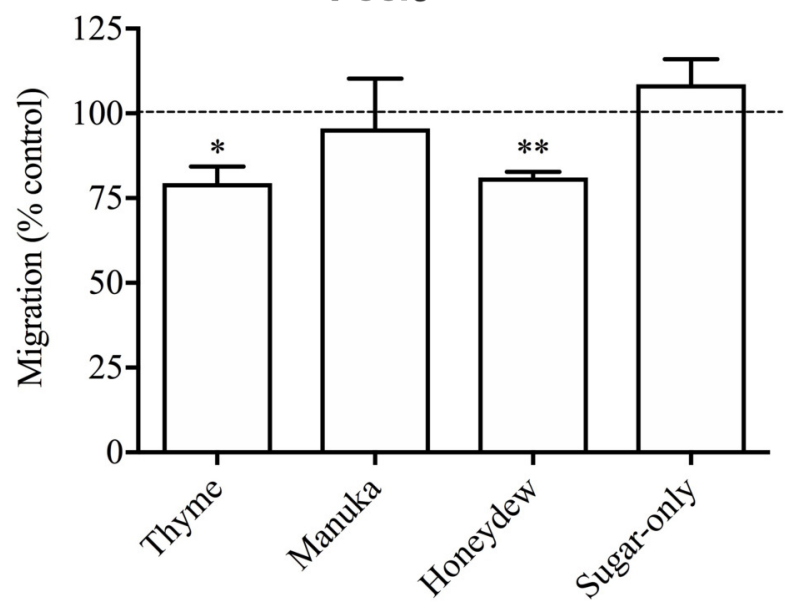

C.

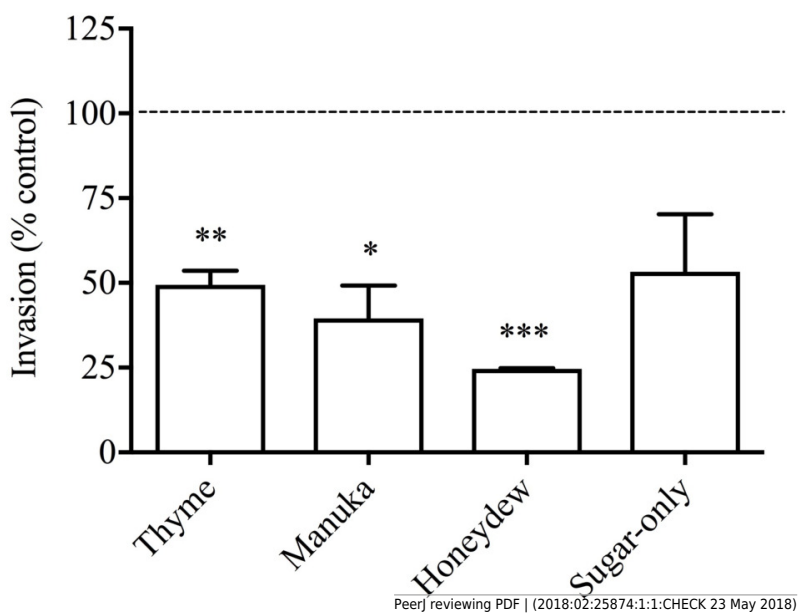

B. 125

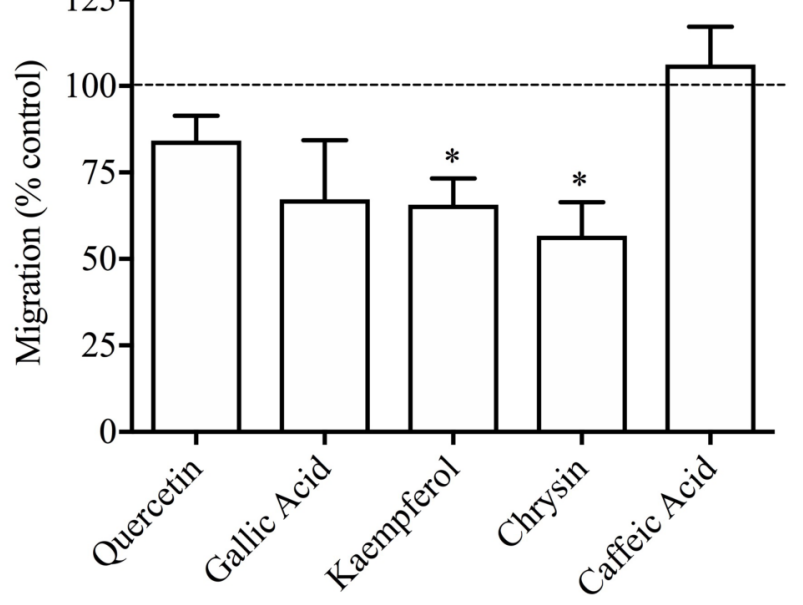

D. 125

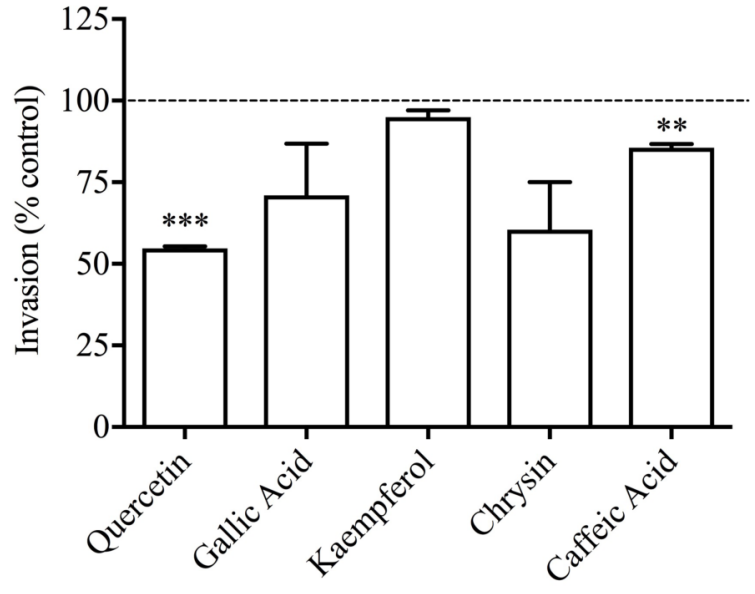


Figure 3 (on next page)

Effect of honey on PC3 and DU145 cell adhesion to collagen I.

(a,b) PC3 and (c,d) DU145 cells were left to adhere to plates coated with collagen I for (a) 30, (b,c) 60 or (d) 90 min. Experiments were completed in triplicate, with results expressed as mean percentage of control \pm S.E.M $(n=$ minimum of 3 ). Individual data were analysed using a two-way ANOVA followed by a Bonferroni post-hoc test, where $p<0.05$ was required for a statistically significant difference. * represents a significant difference between the vehicle-treated control ( $0 \% \mathrm{w} / \mathrm{v}$ RPMI only ) and individual treatment. 

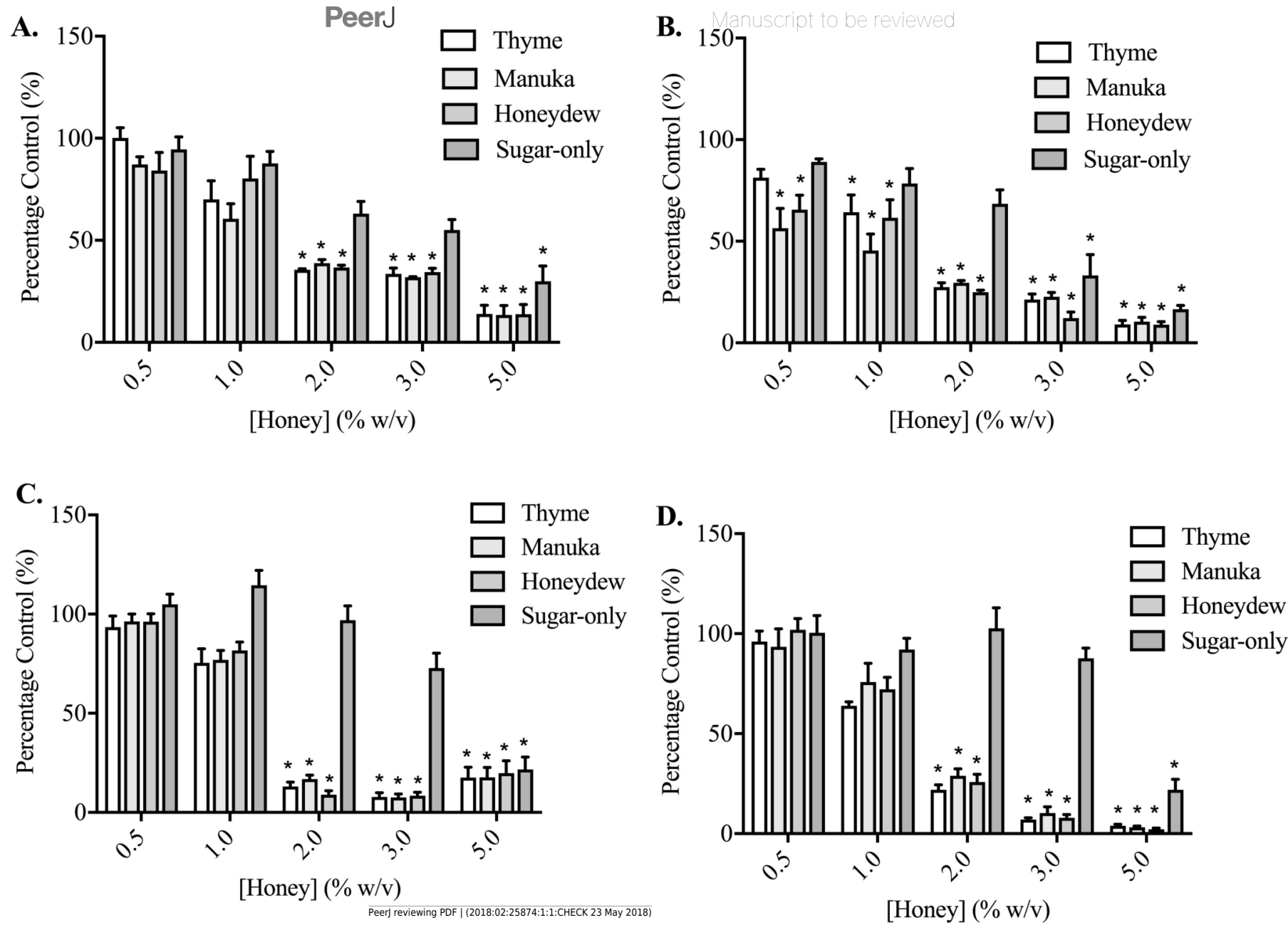
Figure 4 (on next page)

Effect of honey on PC3 and DU145 cell adhesion to fibronectin.

(a,b) PC3 and (c,d) DU145 cells were left to adhere to plates coated with collagen I for (a) 30, (b,c) 60 or (d) 90 min. Experiments were completed in triplicate, with results expressed as mean percentage of control \pm S.E.M $(n=3)$. Individual data were analysed using a twoway ANOVA followed by a Bonferroni post-hoc test, where $p<0.05$ was required for a statistically significant difference. * represents a significant difference between vehicletreated control ( $0 \% \mathrm{w} / \mathrm{v}$ RPMI only ) and individual treatment. 


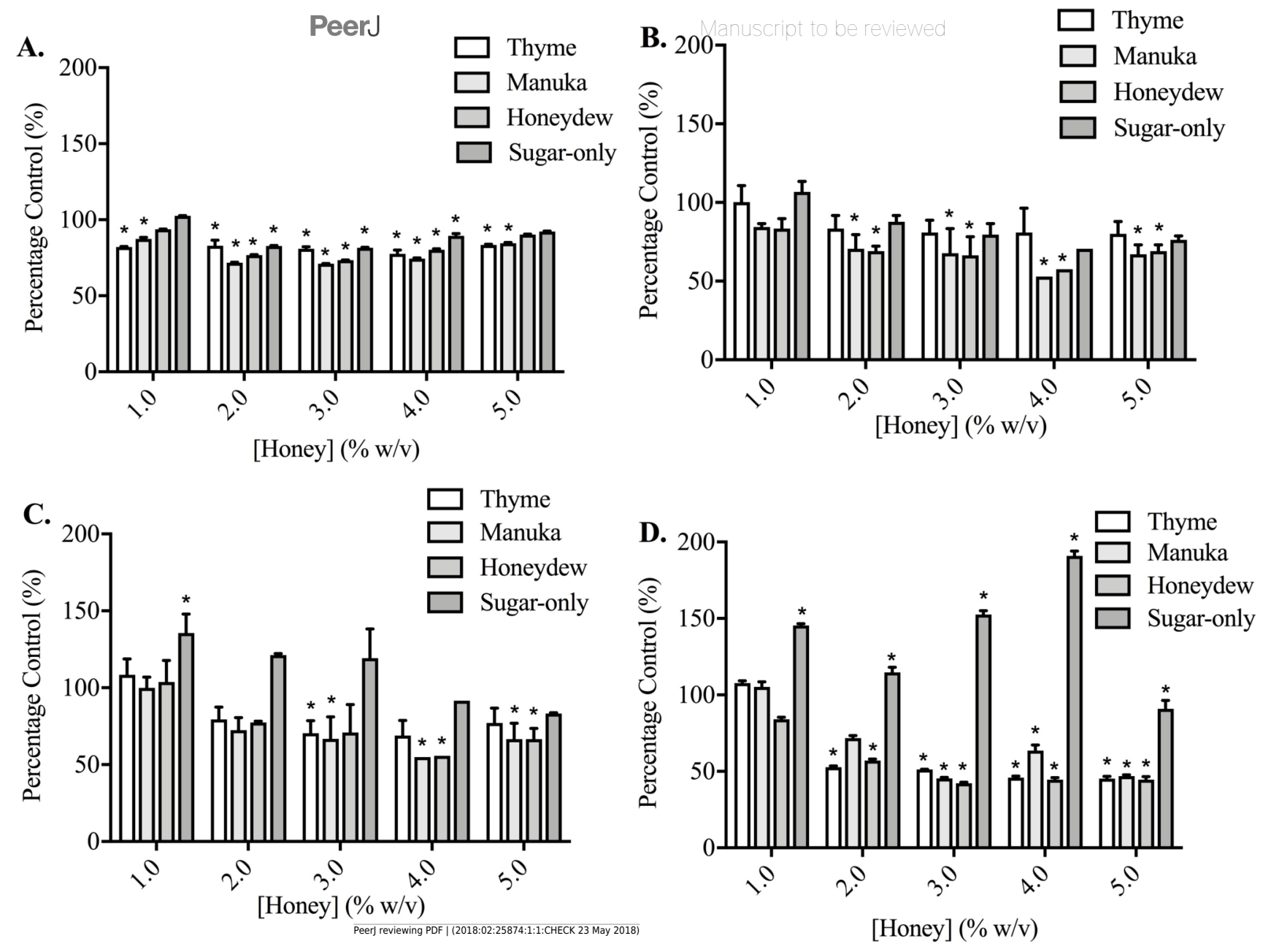




\section{Figure $\mathbf{5}$ (on next page)}

Effect of honey-derived phenolic compounds on PC3 and DU145 cell adhesion.

PC3 and DU145 cells were treated with (a) quercetin $(0-150 \mu \mathrm{M})$, (b) gallic acid (0 - $10 \mu \mathrm{M})$, (c) kaempferol $(0-150 \mu \mathrm{M})$, (d) chrysin $(0-50 \mu \mathrm{M})$ or (e) caffeic acid $(0-50 \mu \mathrm{M})$ for $60 \mathrm{~min}$. Experiments were completed in triplicate, and values were expressed as mean percentage cell viability \pm S.E.M ( $n=2$ or 3 ). Data were analysed using a two-way ANOVA followed by a Bonferroni post-hoc test, where $p<0.05$ was required for a statistically significant difference. * represents a significant difference between control and individual treatment. 

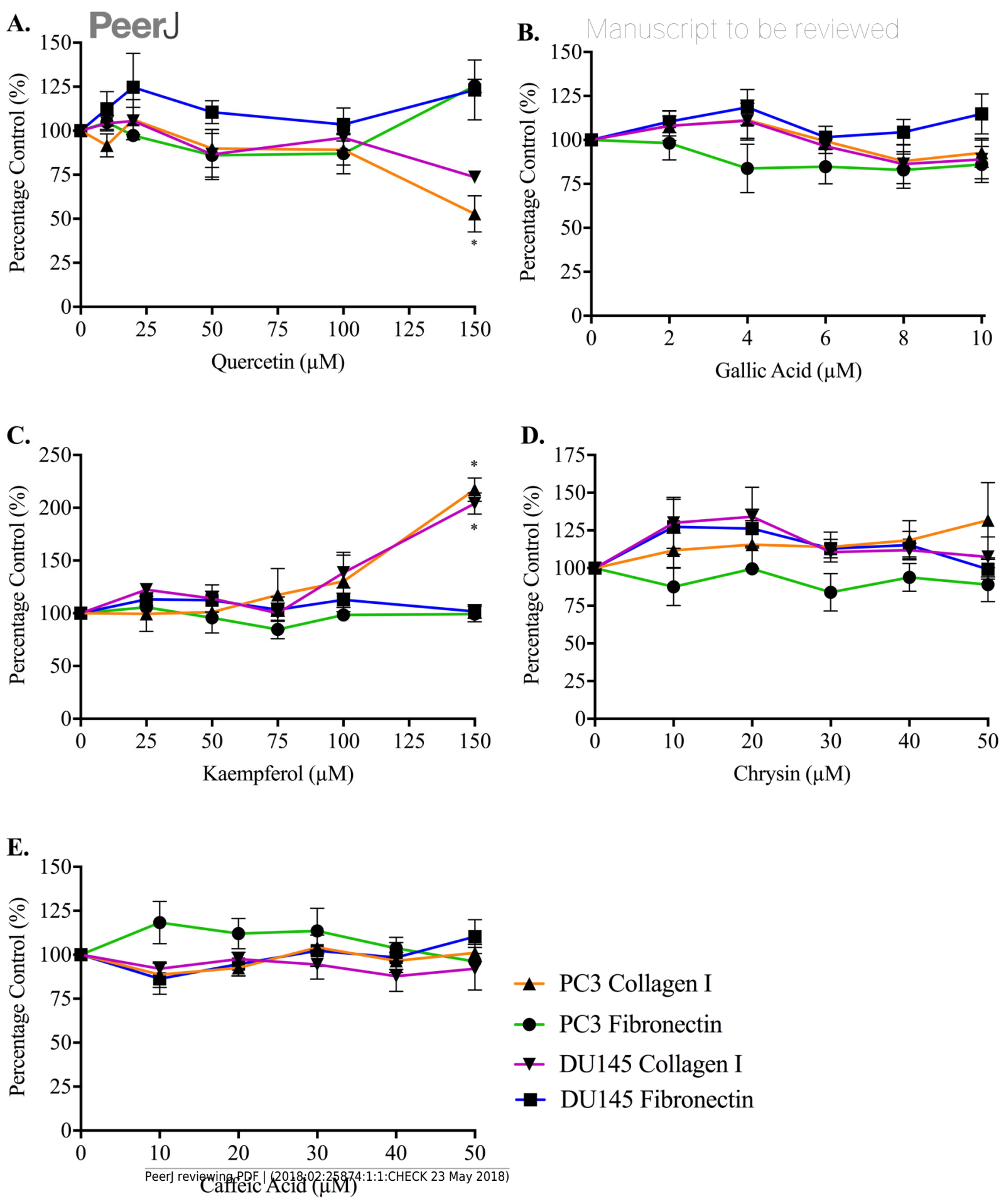